\title{
Strategi Marketing Dompet Dhuafa dalam Peningkatan Kepercayaan Muzakki
}

\author{
Ziyan Lutfiani Noor Falah*, Ahmad Sarbini, \& Yuliani \\ Jurusan Manajemen Dakwah, Fakultas Dakwah dan Komunikasi, \\ UIN Sunan Gunung Djati, Bandung \\ *Email: riyanlutfiani@student.uinsgd.ac.id
}

\begin{abstract}
ABSTRAK
Tujuan penelitian ini untuk mengetahui strategi marketing dan rangkaian kegiatan yang digunakan dompet dhuafa dalam hal kepercayaan muzakei dan peningkatan donasi setiap tahunnya. Peneliti ini menggunakan model S-O-S-T-A-C, model ini pada dasarnya merupakan teori pemasaran yang dijelaskan tentang poin-poin berikut: situasi yang berkaitan dengan keberadaan dimana dan bagaimana sebuah lembaga atau instansi. Objektive yaitu yang berkaitan dengan visi dan misi serta target pencapaian sebuah lembaga. Metode yang digunakan dalam penelitian ini adalah metode deskriptif analisis dengan pendekatan kualitatif. Implementasi Dompet Dhuafa berkontribusi melalui empat bidang Program yaitu Pendidikan, Kesehatan, Sosial Development, Ekonomi dan program incidental di bulan Ramadan. Dari program tersebut terlihat perkembangan jumlah donator setiap tahunnya. Hasil dari Penelitian ini adanya peningkatan yang dilakukan oleh marketing Dompet Dhuafa dalam meningkatkan kepercayaan murakki dengan menggunakan strategi yang telah dirancang oleg marketing dompet dhuafa. Kesimpulan dari penelitian ini bahwa dompet dhuafa yang berhasil menjalankan tugasnya dalam menambah jumlah muzakki dan donasi, telah merancang strategi dari marketing dan peningkatan kepercayaan muqakki di kota bandung. Hal ini tercermin dari misi yang dilaksanakan oleh marketing dompet dhuafa terhadap peningkatan kepercayaan muzakki. Dari proses rekrutmen, sleksi, pelatihan, pembinaan dan motivasi telah dilaksanakan sesuai strategi yang dirancang marketing.
\end{abstract}

Kata Kunci: Strategi, Marketing, Dompet Dhuafa

\section{ABSTRACT}

The purpose of this research is to find out the marketing strategy and the series of activities used by Dhuafa wallet in terms of muzakeki trust and increased donations each year. This researcher uses the S-O-S-T-A-C model, this model is basically a marketing theory which is explained about the following points: situations related to where and where an institution or agency is. Objective, which is related to the vision and mission as well as the achievement target of an institution. The method used in this study is a descriptive analysis method with a qualitative approach. Dompet Dhuafa implementation contributes through four program areas namely Education, Health, Social Development, Economics and incidental programs in the month of 
R. T. Abdullah, Ahmad Sarbini, \& Yuliani

Ramadan. From the program, the number of donors is seen every year. The results of this study are the improvements made by marketing Dompet Dhuafa in increasing murakei trust by using strategies that have been designed by marketing dhuafa wallet. The conclusion of this study that dhuafa wallet that succeeded in carrying out its duties in increasing the number of muzakeki and donations, has devised a strategy of marketing and increased muaakki trust in the city of Bandung. This is reflected in the mission carried out by the dhuafa marketing wallet towards increasing the murakei trust. From the recruitment, slection, training, coaching and motivation processes have been carried out according to the marketing designed strategy

Keywords: Strategy, Marketing, Dompet Dhuafa

\section{PENDAHULUAN}

Permasalahan yang sering timbul di tengah masyarakat terutama di kalangan masyarakat Bandung adalah kepada siapa zakat harus diberikan. Lebih utama disalurkan langsung oleh muzakki kepada mustabiq, atau sebaiknya melalui amil. Jika disalurkan langsung oleh muzakki kepada mustabiq, memang ada semcam perasaan tenang karena menyaksikan secara langsung bahwa zakatnya tersebut telah tersalurkan kepada mereka yang dianggap berhak menerimanya.

Tetapi terkadang penyaluran langsung yang dilakukan oleh muzakki tidak mengenai sasaran yang tepat. Seringkali orang sudah merasa menyalurkan zakat kepada mustahiq, padahal ternyata yang menerima bukan mustahiq yang sesungguhnya, hanya karena kedekatan secara emosi maka murakki memberikan zakat kepadanya. Misalkan disalurkan kepada kerabatnya sendiri, yang menurut anggapannya sudah termasuk kategori mustahiq, padahal jika dibanding dengan orang-orang yang berada dilingkungan sekitarnya, masih banyak orang-orang yang lebih berhak untuk menerimanya (Setiawan, 2012).

Masalah ini harus diantisipasi agar pengelolaan zakat terlaksanan sesuai dengan metode yang dicontohkan Rasululloh SAW. Oleh karena itu peran lembaga amil zakat diperlukan. Hal tersebut terjadi salah satunya karena kreadibilitas dari lembaga Dompet Dhuafa belum mendapat perhatian dari muzakki. Ini akan menjadi perhatian yang sangat penting ketika masyarakat ingin melihat peningkatan kreadibilitas dari seorang amil. Kepuasan terhadap pelayanan lembaga Dompet Dhuafa akan mendorong perilaku muqakki dalam berzakat berupa komitmen terha dap lembaga amil zakat tersebut, menjadikan lembaga Dhompet Dhuafa tersebut sebagai pilhan utama dalam berzakat dan mengajak orang lain untuk berzakat.

Selaku lembaga pengumpul dana, Dompet Dhuafa memang boleh dibilang punya strategi marketing yang andal. Mereka selalu berinovasi dalam hal mengumpulkan dana sumbangan. Prinsipnya, orang yang mau menyumbang harus dipermudah. Mereka juga menjadi pelopor sistem kanvasing, datang ke rumahrumah mengambil sumbangan.

Stategi peningkatan kepercayaan muzakki terhadap Dompet Dhuafa tidak saja menjadi tugas dari marketing Dompet Dhuafa, akan tetapi tangggung jawab seluruh jajaran pengurus Dompet Dhuafa. Kepercayaan muzakki akan 
memberikan kekuatan bagi lembaga atau perusahaan, kepercayaan itu harus terus di pertahankan dan terus di tingkatkan. Dengan strategi khusus untuk meningkatkan kepercayaan murakki terhadap Dompet Dhuafa maka seluruh masyarakat Indonesia akan menaruh simpati dan percaya kepada lembaga Dompet Dhuafa.

Pengertian strategi secara umum adalah proses penentuan rencana para pemimpin puncak yang berfokus pada tujuan jangka panjang organisasi, disertai penyusunan puncak yang berfokus pada tujuan japenrtaingka panjang organisasi, disetrai penyusunan satu cara atau upaya bagaimana agar tujuan tersebut dapat dicapai. Adapun Adapun pengertian stapengertian srtartategi scara khusus merupakan tindakan yang bersifat incremental (senantiasa meningkat) dan terusmenerus, serta dilakukan berdasarkan sudut pandang tentang apa yang diharapkan oleh para pelanggan di masa depan. Dengan demikian, strategi hampir selalu dimulai dari apa yang dapat terjadi dan bukan dimulai dari apa yang terjadi. Terjadinya kecepatan inovasi pasar yang baru dan perubahan konsumen memerlukan lompetensi inti (core conpetencies). Perusahaan perlu mencari kompetansi inti di dalam bisnis yang dilakukan.

Istilah strategi menurut Stainer dan Miner (iriantara, 2004 : 12), yaitu "strategi mengacu pada formulasi misi, tujuan dan objektif dasar perusahaan, strategi-strategi program dan kebijakan utuk menciptakannya, dan metode yang diperlukan untuk memestikan bahwa strategi di implementasikan untuk mencapai tujuan-tujuan perusahaan". Sedangkan Porter (iriantara, 2004 : 12) mengartikan strategi adalah "sebagai formula berbasis luas mengenai cara bisnis bersaing tujuan apa yang ingin dicapai, dan kebijakan apa yang diperlukan untuk mencapai tujuan tersebut.

Istilah strategi sering pula disebut rencana strategis atau rencana jangka panjang lembaga/perusahaan. Strategi meruoakan simpul taktik dalam keperluan bagaimana tujuan yang diinginkan dapat diperoleh atau didapat. Oleh sebab itu strategi biasanya terdiri atas dua atau lebih taktik, dengan anggapan yang satu lebih bagus dari yang lain. Dengan demikian strategi merupakan kumpulan taktik dengan magsud untuk mencapai tujuan dan sasaran dari perusahaan, institusi atau badan.

Penggunaan strategi marketing akan sangan di bantu dan dipermudah terhadap pencapaian visi dan misi lembaga atau perusahaan. Oleh karena itu, posisi marketing di beberapa perusahaan besar di Indonesia sudah di tempatkan di posisi yang sangat strategis. Sehingga, keberadaan marketing akan sangat teluasa dalam menjalan perndan fungsinya secara professional terutama yang menyangkut dengan masaah perubagan lingkungan sosial. Salah satu kunci keberhasilan marketing dalam satu lembaga/perusahaan yaitu kemampuan marketing dalam mengadaptasikan dalam perubahan lingkungan sosial, karena kemampuan ini akan berimplikasi terhadap citra public pada lembaga atau perushaan bahkan lebih dari itu dapat menarik minat masyarakat untuk mempercayakan suatu kepentingan dilembaga atau perusahaan tersebut. 
Strategi Marketing adalah pernyataan pokok tentang dampak yang diharapkan akan dicapai dalam hal permintaan pada dasar target tertentu. Pendekatan terinci untuk menerapkan strategi-strategi ini di tentukan oleh program-program pemasaran yang spesifik, seperti program periklanan, program promosi penjualan, program pengembangan produk, serta program penjualan dan distribusi (Agus Maulana, 1992: 157)

Kepercayaan adalah pernyataan yang jumlahnya sangat banyak (mencpai ratusan ribu) yang dibuat seseorang mengenai dirinya dan lingkungannya. (Milton Rokeach, Belief, Attitudes and Values, A Theory OF Organization and Changed, Joeesy-Bass Francisco 1969 : 70)

Murakki adalah orang atau badan yang dililiki umat muslim yang berkewajiban memnunaikan zakat (Undang-undang Republik Indonesia Nomor 38 Tahun 1999127). Jika disimpulkan kepercayaan murakki adalah ketika seorang muzakei menganbil suatu keputusan, ia akan akan lebih memilih keputusan bedasarkan pilihan dai orang-orang yang lebih dapat dipercaya dari pada yang kurang dipercayai.

Pendekatan dalam membangun strategi marketing untuk mencapai suatu tujuan sebuah lembaga, salah satunya yaitu dengan teori Robbins, secara umum membagi strategi ke dalam dua kategori, yaitu, strategi internal dan strategi eksternal.

Penelitian ini dilaksanakan di Dompet Dhuafa yang terletak di jalan Naripan No. 106 Blok C Bandung. Penelitian ini membahas tentang strategi Program Marketing di Dompet Dhuafa dalam Meningkatkan Kepercayaan Muqakki, implementasi Program Marketing Dompet Dhuafa dalam Meningkatkan Kepercayaan Murakeki dan hasil Implementasi program Marketing Dompet Dhuafa dalam Meningkatkan Kepercayaan Muzakki.

\section{METODE PENELITIAN}

Metode penelitian yang digunakan adalah metode deskriptif, yaitu untuk menggambarkan tentang karakteristik (ciri-ciri) individu, situasi atau kelompok tertentu. Penelitian ini relatif sederhana yang tidak memerlukan landasan teoritis yang rumit atau kemajuan hipotesis tertentu. (Ruslan, 2010 : 14).

Penelititian deslriptif kualitatif ini diajukan untuk (1) mengumpulkan informasi actual secara rinci yang melukiskan gejala yang ada dilokasi penelitian, (2) mengidentifikasi masalah atau memeriksa kondisi dan kegiatan yang ada dilokasi penelitian, (3) membuat perbandingan atau evaluasi, (4) menentukan apa yang dilakukan orang lain dalam menghadapi masalah yang sama dan belajar dari pengalaman mereka menentukan serta menetapkan rencana dan keputusan dalam memecahkan suatu masalah pada waktu yang akan datang.

Sumber data yang digunakan dalam penelitian ini adalah sumber data primer dan sumber data sekunder. Sumber data primer diperoleh dari Kepala Dompet Dhuafa beserta Staf ahlinya sedangkan sumber data sekunder diperoleh berdasarkan kajian berbagi literatur dalam studi kepustakaan, kepustakaan yang 
dipakai yaitu buku-buku bacaan tentng marketing, dokumen, kliping, dan sumber lain yang mendukung dan berkaitan dengan masalah penelitian.

Jenis data yang digunakan dalam penelitian ini sbagai berikut: Data langkahlangkah marketing Dompet Dhuafa menyusun strategi dalam meningkatkan kepercayaan muzaki Data bagaimana implementasi yang dilakakan marketing Dompet Dhuafa dalam meningkatkan kepercayaan muzakki. Data bagaimana hasil yang didapatkan marketing Dompet Dhuafa dalam meleksanakan langkahlangkah dan implementasi strategi tersebut.

Adapun teknik yang digunakan untuk mengumpulkan data dalam penelitian ini adalah sebagai berikut: pertama, Wawancara adalah salah satu teknis pengumpula data dalam metode survey melalui daftar pertanyaan yang di ajukan secara lisan terhadap responden (subjek). Biasanya daya yang dukumpulkan bersifat kompleks, sensitive dan kontrofersial sehingga menyebabkan kurang mendapat respon dari sebjeknya, apalagi kalau responden tidak dapat membaca dan menulis atau kurang memahi pertanyaan tersebut. (Ruslan, 2010: 23).

Kedua, Observasi dapat diartikan untuk mengadakan oenelitian dengan jalan mengadakan pengamatan dan pencatatan secara sistematis terhdap gejala yang diteliti. Penelitian ini melakukan pengamatan no pasrtisipan, melakukan observasi pengumpulan data dan informasi tanpa melibatkan diri, atau tidak menjadi bagian dari lingkungan sosial ataw organisasi yang di amati. (Ruslan, 2010:36)

Ketiga, Studi pustaka adalah menelusuran berbagai literature yang dilakukan untuk mencari data atau informasi membaca jural ilmiah, buku-buku referensi, dan bahan publikasi yang tersedia di perpustakaan (Ruslan, 2010: 31).Studi dokumentasi adalah penelusuran berbagi informasi yang berasal dari tempat penelitian. Studi ini penulis lakukan untuk mendapatkan data yang diperlukan untuk penelitian penulis

Analisis data dilakukan setelah data terkumpul. Analisis data merupakan proses mengoragaisasikan dan mengurutkan data kedalam pola kategori dan satuan uraian dasar sehingga dapat di temukan tema, maka dalam penelitian ini analisis data yang dilakukan menggunakan analisis data kualitatif. Proses analisis data dimulai dengan menelaah seluruh dat yang tersedia dari berbagai sumber, yaitu dari observasi dan wawancara. Setlah di baca, dipelajari, dan ditelaah maka langkah berikutnya mengadakan reduksi data yang dilakukan dengan cara membuat abstraksi. Langkah selanjuynya adalah penyunsunan dalam satuansatuan itu kemudian dikategorisasikan pada langkah berikutnya. Tahapan akhir dari analisis data ini adalah mengadakan pemeriksaan keabsahan data serta mengambil kesimpulan.

Menurut Ruslan Rusadi analis data dilakukan dengan 5 cara, yaitu: Klasifikasi dan kategorisasi data, Reduksi data, adalah pengertian ulang dari semua data dan uraian yang terarah sistematis, Display data, adalah paparan data diserati analisis awal, Mencari hubungan data dengan teori-teori studi kepustakaan, Kesimpulan dan verifikasi, data yang sudah dikumpulkan kemudian dijadikan 
sebuah laporan tertulis.

\section{HASIL DAN PEMBAHASAN}

Dompet Dhuafa Republika adalah lembaga nirlaba milik masyarakat indonesia yang berkhidmat mengangkat harkat sosial kemanusiaan kaum dhuafa dengan dana ZISWAF (Zakat, Infaq, Shadaqah, Wakaf, serta dana lainnya yang halal dan legal, dari perorangan, kelompok, perusahaan/lembaga). Kelahirannya berawal dari empati kolektif komunitas jurnalis yang banyak berinteraksi dengan masyarakat miskin, sekaligus kerap jumpa dengan kaum kaya. Digagaslah manajemen galang kebersamaan dengan siapapun yang peduli kepada nasif dhuafa. Empat orang wartawan yaitu Parni Hadi, Haidar bagir, S. Sinansari Ecip, dan Eri Sudewo berpadu sebagai Dewan Pendiri lembaga independen Dompet Dhuafa Republika.

\section{Strategi Program Marketing Dompet Dhuafa Jawa Barat dalam Meningkatkan Kepercayaan Muzakki}

Penghimpunan dana (fundraising) adalah suatu kegiatan dalam rangka penggalangan dana dan daya lainnya dari masyarakat yang akan digunakan untuk membiayai program dan kegiatan operasional lembaga sehingga mencapai tujuan. Dengan begitu strategi penghimpunan (fundraising) dapat diartikan sebagai proses mempengaruhi masyarakat atau calon donator agar mau melakukan amal kebajikan dalam bentuk penyerahan dana atau sumber daya lainnya yang bernilai, untuk disampaikan kepada masyarakat yang membutuhkan (April Purwanto, 2009: 12).

Dalam setiap lembaga pasti ada target yang harus dicapai dalam waktu satu tahun ke depan. Begitu pula dengan Dompet Dhuafa Jabar juga menentukan target penerimaan dana ZIS setiap tahunnya. Dompet Dhuafa Jabar dalam mencapai target penghimpunan dana (fundraising) zakat tersebut, setidaknya ada 3 komponen strategi yang telah digunakan oleh Dompet Dhuafa Jabar, yaitu, Komunikasi, Layanan dan Event.

Pada umumnya komunikasi terdiri atas dua jenis, yaitu komunikasi vertikal dan horizontal. Komunikasi vertikal terdiri atas komunikasi ke bawah dan keatas. Komunikasi ke bawah berasal dari manajemen puncak mengalir ke bawah, melalui jejaring hierarki manajemen hingga ke staff paling bawah. Biasanya berupa pengarahan, intruksi atau saran dan nasihat. Sedangkan komunikasi ke atas merupakan informasi dari bawah ke atas, biasanya dalam bentuk laporan keuangan, permintaan keputusan atau usulan.

Komunikasi horizontal sifatnya lebih familier ketimbang vertikal. Ada dua wilayah cakupan komunikasi horizontal yaitu, komunikasi antara anggota dalam satu bidang atau kelompok kerja, dan komunikasi antara kelompok, antar bidang atau antar departemen. Komunikasi horizontal punya arti penting, bahkan terkadang bisa jadi penyeimbang tak sehatnya komunikasi vertikal. Atau melalui komunikasi horizontal, klarifikasi suatu masalah dapat diselesaikan (Erie Sudewo, 2012: 252-253). 
Komunikasi yang efektif adalah komunikasi yang tidak hanya pada ketersampaian pesan kepada publik, namun juga berkaitan dengan citra lembaga. Karena setiap lembaga harus dapat membangun komunikasi yang dialogis dengan masyarakat baik secara pemberi maupun sebagai penerima, hal ini dimaksudkan agar mereka dapat menaruh kepercayaan terhadap suatu lembaga.

Perkembangan yang dialami oleh Dompet Dhuafa Jabar juga tidak terlepas dari adanya komunikasi yang baik dengan masyarakat, karena jika kurangnya komunikasi akan memperlambat perkembangan, dengan begitu adanya komunikasi sangat erat kaitanya dengan perkembangan yang akan dialami oleh suatu lembaga amil zakat.

Strategi komunikasi yang telah dilakukan oleh Dompet Dhuafa Jabar adalah dengan melakukan kampanye-kampanye yang setiap tahunya tema yang diangkat berganti-ganti sesuai dengan isu tertentu. dengan bagitu tujuan dari kampanye tersebut adalah memberi informasi langsung dan mengajak donatur untuk berdonasi, dan menumbuhkan kesadaran berzakat pada warga Jabar khususnya Kota Bandung yang sudah wajib mengeluarkan zakatnya.

Layanan adalah setiap kegiatan atau manfaat yang ditawarkan suatu pihak kepada pihak lain yang pada dasarnya tidak berwujud dan tidak mengakibatkan kepemilikan apapun (Bilson Simamora, 2001: 172).

Selain komunikasi, layanan juga merupakan salah satu strategi yang di lakukan oleh Dompet Dhuafa Jabar dalam proses penghimpunan dana ZIS. Dengan adanya layanan ini akan dapat menarik minat donatur untuk berdonasi. Dalam hal ini terkait tentang informasi kepada donatur, kemudahan komunikasi, tempat pelayanan, kecepatan dan kemudahan pembayaran.

Dengan memberikan pelayanan yang memuaskan kepada donatur adalah salah satu hal yang sangat penting bagi sebuah lembaga nirlaba, karen dengan pelayanan yang baik dan memuaskan, maka akan memberikan kesan positif kepada donatur shingga akan mengulanginya kembali untuk membayarkan zakatnya.

Dengan demikian, kepercayaan dan pelayanan yang berkualitas merupakan kebutuhan donatur dan muzakki yang harus dipenuhi oleh LAZ. Sedangkan efektifitas layanan yang dilakukan Dompet Dhuafa Jabar ialah dengan memberi kemudahan yang semudah-mudahnya agar donatur atau muzakeki mudah membayar zakatnya di Dompet Dhuafa Jabar, dengan begitu tidak ada alas an bagi muzakkei untuk susah membayar zakatnya. Kemudahan layanan yang diberikan Dompet Dhuafa Jabar antara lain; layanan jemput zakat, pembayaran melalui rekening, layanan konsultasi zakat, kalkulator zakat dan lain sebagainya.

Disamping komunikasi dan layanan, event fundraising adalah event yang biasa diselanggarakan dengan maksud memanfaatkan keuntungan event untuk program sosial. Dalam rangka mengoptimalkan potensi ZIS mengadakan kerjasama secara teknis dengan perusahaan dilakukan agar penghimpunan ZIS 
lebih optimal.

Sedangkan event yang dilakukan oleh Dompet Dhuafa Jabar adalah seperti menjalin kerjasama dengan lembaga lain, konser amal, pengajian kantor, golf peduli dan lain sebagainya.

Disamping menggunakan tiga komponen strategi diatas, terdapat pula metode-metode yang digunakan oleh setiap lembaga zakat untuk membantu penghimpunan dana ZIS.

Pada umumnya sebuah lembaga amil zakat melakukan dua model metode penghimpunan (fundraising) yaitu: metode fundraising langsung (direct fundraising) dan fundraising tidak langusung (indirect fundraising).

Metode fundraising langsung. Adalah metode yang menggunakan teknikteknik atau cara yang melibatkan partisipasi donatur secara langsung, yaitu bentuk fundraising dimana proses interaksi terhadap respon donatur bisa seketika (langsung) dilakukan. Sebagai contoh dari metode ini adalah: direct mail, direct advertising, telemarketing, dan presentasi langsung.

Metode fundraising tidak langsung. Adalah suatu metode yang menggunakan teknik atau cara yang tidak melibatkan partisipasi donatur secara langsung, yaitu bentuk fundraising dimana tidak dilakukan dengan memberikan daya akomodasi langsung terhadap respon donatur seketika. Metode ini biasanya dilakukan dengan cara promosi yang mengarah kepada pembentukan citra lembaga yang kuat, sebagai contohnya adalah image compaign dan penyelenggara event (Direktorat Pemberdayaan Zakat Direktorat Jendral Bimbingan Masyarakat Islam Departemen Agama RI, 2009: 69).

Sedangkan Dompet Dhuafa Jabar menggunakan dua model metode yaitu; Above the line dan bellow the line.(1)Above the line, yaitu komunikasi melalui media massa sebagai sarana mempromosikan brand atau merk berbasis media elektronik, Atau biasa disebut dengan serangan udara. Seperti TV, Radio, Koran, Media Sosial.(2)Bellow the line, yaitu teknik periklanan yang lebih spesifik dalam memasarkan produk atau layanannya yang dapat berupa aktivitas yang berhubungan atau berinteraksi secara langsung dengan donatur atau biasa disebut dengan melalui serangan darat, seperti contohnya:(3)Kanvasing merupakan kegiatan marketing yang dilakukan setiap lembaga secara door to door/ bertemu langung dengan donatur atau masyarakat. (4)Sebar Brosur (5)Telemarketing adalah bentuk direct marketing yang efektif terutama untuk donasi berulang dan mampu memberikan kesan dan interaktif. (6) Directmail adalah pengiriman surat penawaran yang ditujukan langsung kepada para calon donatur melalui email, mobail mail sms, faxmail dan BBM. (7)Membuka konter adalah cara komunikasi yang cukup baik untuk dilakukan, dan sasaran berada di titik pusat perbelanjaan dan perkantoran dalam rangka untuk melakukan komunikasi sosialisasi dan edukasi, disamping melakukan seminar dan diskusi publik.

\section{Implementasi Program Marketing Dompet Dhuafa dalam Meningkatkan}




\section{Kepercayaan Muzakki.}

Dalam melakukan impementasi program tentu haruslah mempertimbangkan analisis SWOT karena dengan melakukan analisis SWOT ini akan terlihat sejauhmana implementasi program tersebut bias dilaksanakan. Dengan analisis SWOT akan terlihat peluang atau ancaman yang akan terjadi nantinya dalam implementasi program tersebut.

Dalam melakukan implementasi program marketing Dompet Dhuafa tentu menggunakan fungsi manajemen yaitu POAC. Fungsi manajemen ini sangatlah penting yang mana marketing Dompet Dhuafa harus merencanakan secara matang program yang inngi dilakukan, dan pelaksanaannya apakah berjalan dengan baik, siapa saja tim yang bertanggung jawab dalam mengsukseskan stiap program dan terakhr adalah controlnya, control harus dilakukan oleh pihak marketing apakah program-program yang telah terlaksanakan memberikan konstribusi yang baik untuk kepercayaan Dompet Dhuafa.

Dalam wawancara yang saya lakukan dengan bapa M Faris Selaku Manajer Fundraising dan komunikasi di Kantor Pusat Dompet Dhuafa Jabar. Dalam wawancara tersebut beliau mengatakan program Dompet Dhuafa dalam implementasi Marketing Dompet Dhuafa berupa program-program untuk mengkatkan kepercayaan Muzakki.

Dompet Dhuafa berkontribusi melalui empat bidang Program, yaitu: Pertama, Kesehatan. Dompet Dhuafa di dalam program kesehatan, mendirikan berbagai lembaga kesehatan yang bertujuan untuk melayani seluruh mustahik dengan sistem yang mudah dan terintegrasi dengan sangat baik. Di bidang kesehatan, Dompet Dhuafa telah berperan aktif dalam melayani kaum dhuafa sejak tahun 2001. Melalui program Layanan Kesehatan Cuma-cuma (LKC), beragam kegiatan telah dilakukan, baik bersifat preventif, promotif dan kuratif. Sejak tahun 2009, Dompet Dhuafa membangun rumah sakit gratis bagi pasien dari kalangan masyarakat miskin. Berlokasi di Desa Jampang, Kemang, Kabupaten Bogor, di atas lahan seluas 7,600 m2. RST memiliki fasilitas lengkap, mulai dari poliklinik, dokter spesialis, ruang operasi, rawat inap, UGD, apotek, hingga metode pengobatan komplementer

Kedua, Pendidikan. Pendidikan merupakan aset nasional yang berharga dan menjadi tolok ukur kemajuan sebuah bangsa. Pendidikan bisa me Beastudi Peduli Program pemberian beasiswa kepada siswa SD - Perguruan Tinggi bagi siswa yang berasal dari keluarga miskin. Khusus untuk tingkat Perguruan Tinggi diberikan fasilitas asrama dan pembinaan.

Program pembinaan dan pendampingan bagi anak-anak dhuafa yang beraktivitas sebagai pemulunguntuk membantu orangtuanya dalam memenuhi kebutuhan harian keluarga. Berlokasi di pemukimanpemulung atau TPA (Tempat Pembuangan Akhir) Sampah, Pasar Rau, Serang. Untuk meningkatkan minat baca sekaligus menanamkan akhlak dan karakter positif sedari dini melaluikonsep mendongeng, targetnya adalah anak-anak di titik-titik kantung kemiskinan Dompet DhuafaBanten yang kesulitan untuk mendapatkan akses perpustakaan 
atau taman baca.

Program pelatihan keterampilan kerja bagi para pengangguran usia produktif. Bentuk pelatihan yang diberikan antara lain servis HP - Motor, Fashion, Tata Boga, Bahasa Asing, Mengemudi, Design Grafis, dan IT. Peserta diberikan pelatihan dalam bentuk materi dan praktek oleh pendidik profesional,kemudian diberikan pendampingan usai pelatihan sampai mereka bekerja maupun membuka usaha mandiri. Makmal Pendidikan adalah sebuah laboratorium pendidikan yang berusaha menjawab kebutuhan peningkatan kualitas guru dan sekolah melalui pelatihan guru, pendampingan, dan forum Sahabat Guru Indonesia (SGI). Program kegiatan yang ada di Makmal Pendidikan adalah Pendampingan Sekolah, Pelatihan Guru, dan Pusat Sumber Belajar. 1. Pendampingan Sekolah Pendampingan sekolah adalah model pengembangan sekolah dalam meningkatkan kualitas manajemen, kegiatan belajar mengajar, dan partisipasi masyarakat di bidang layanan pendidikan. 2. Pelatihan Guru Pelatihan Guru adalah pelatihan dan workshop yang dirancang sistematis berdasarkan standar kurikulum berbasis kompetensi dan merupakan sarana yang efektif untuk meningkatkan kemampuan mendidik dan mengajar guru pada satu kompetensi tertentu yang bersifat khusus dan terencana. 3. Pusat Sumber Belajar (PSB) Pusat Sumber Belajar (PSB) merupakan salah satu departemen di bawah Makmal Pendidikan yang berfokus pada pengembangan, inovasi dan pengembangan kreativitas pengajaran. Pusat Sumber Belajar melayani masyarakat secara luas dan khususnya para guru melalui beberapa program atau kegiatan yaitu Perpustakaan SMART EI dan Pusat Media Pembelajaran. Jangkauan dan Jumlah Penerima Manfaat

Ketiga, Ekonomi. Masalah sosial yang dihadapi bangsa ini sejak dulu adalah kemiskinan. Berbagai program dan kebijakan yang telah dilakukan belum mampu mengatasi masalah kemiskinan di negeri ini. Meski pertumbuhan ekonomi melesat namun Indonesia masih diselimuti kemiskinan yang dahsyat. Untuk itu Dompet Dhuafa mendirikan divisi ekonomi dengan jejaring yang tersebar di hampir seluruh pelosok Indonesia. Tujuannya adalah untuk mendampingi masyarakat melalui berbagai program yang disesuaikan dengan daerahnya agar tercipta lahanlahan pekerjaan baru serta masyarakat yang berdaya sehingga mereka dapat mandiri secara finansial.

Ibu Kreatif Banten Program pemberdayaan dan pendampingan komunitas ibu-ibu dari keluarga kurang mampu untuk mengembangkan usaha melalui pemberian modal secara cuma-cuma sesuai potensi lokal yang ada, mulai dari proses produksi hingga pemasaran. misal emping, sate bandeng, ikan asin, kue tradisional, kerajinan, dll. Komunitas usaha tersebut dibentuk koperasi untuk menambah kesejahteraan anggota. (b) Insan Tangguh Merupakan Bantuan baik pemebrian modal maupun pendampingan Pada Individu tangguh yang dengan keterbatasan mereka tetap berusaha dalam mencari rezeki yang halal. (C)Taman Buah Produktif merupakan Sedekah pohon produktif yang yang di desain menjadi taman untuk wisata buah, sehingga selain bisa membantu mustahik, juga bisa menumbuhkan perekonomian di sekitar wilayah tersebut. D) Kampung Wisata. 
Merupakan sebuah program terpadu antara kolam usaha santri, charity, sedekah pohon, beastudi pendidikan dan rekreasi edukasi (wisata zakat) di daerah Cinangka, Anyer, yang lokasinya dekat dengan objek wisata pantai di Anyer. E) Kolam Usaha Santri. Program ini adalah pemberian modal budidaya ikan serta pelatihan budidaya ikan bagi santri di Banten, terutama bagi pesantren yang memiliki kolam ikan yang tidak produktif. Pendampingan program ini dilakukan minimal selama 6 bulan yang dilakukan oleh Dompet Dhuafa Banten. Selain hasil ikannya bisa di konsumsi, diharapkan program ini juga bisa menjadi ladang penghasilan tambahan bagi santri/pesantren. Ikan yang dibudidayakan adalah ikan yang laku di pasaran dan masa panennya cepat seperti lele, ikan mas, nila dan sebagainya.

Keempat, Social Trust Fund. Salah satu entitas penting yang digunakan masyarakat modern terkait dengan praktek finansial adalah bank. Namun karena sejak awal bank adalah entitas komersial yang berorientasi profit, maka dalam prakteknya, bank sangat selektif. Untuk menjaga keamanan dan kelangsungan finansial yang dijalankan, maka bank harus memilih nasabah potensial yang mampu mengembalikan uang dan mampu menghasilkan pendapatan bagi bank. Bermunculanlah serangkaian persyaratan bagi bank untuk dapat menyalurkan dana pembiayaannya.

Akibat selektivitas bank tersebut, banyak orang miskin yang tidak dapat dilayani. Pertimbangannya adalah karena kebanyakan orang miskin, tidak memiliki usaha atau pendapatan yang mapan. Orang miskin juga tidak memiliki aset untuk digunakan sebagai jaminan. Ujungnya adalah orang miskin dinilai tidak layak bertransaksi dengan bank, dan bank pun menjauh dari orang miskin.

Mengatasi hal tersebut, muncullah 'bank' yang dikreasi untuk orang miskin. Beragam entitas keuangan untuk orang miskin sudah coba direkayasa dan dipraktekkan. Dari Mulai Bank Perkreditan Rakyat, Koperasi Simpan Pinjam, sampai kepada lembaga keuangan mikro. Praktek Grameen Bank (asal Bangladesh) yang dianggap sebagai "bank untuk orang miskin" pun banyak ditiru di Indonesia. Dalam khazanah perkembangan lembaga keuangan syariah, juga sudah dikembangkan Baitul Mal wa Tamwil (BMT) sebagai lembaga keuangan untuk melayani orang miskin. Dalam perkembangan selanjutnya, BMT ini kemudian dipayungi oleh badan hukum Koperasi Jasa Keuangan Syariah (KJKS).

Namun, karena watak investasi bisnis yang dimiliki, serta orientasi mengejar laba yang memandu, semua lembaga keuangan untuk orang miskin itu perlahan tapi pasti menguatkan sektor komersialnya. Bahkan sebagian besar sudah menempatkan aspek sosial dalam struktur keuangan yang sangat minimalis. Ratarata sumbangsih aktivitas sosialnya kurang dari 5 persen dalam rasio keuangan. Ini mengindikasikan melemahnya watak menolong sejati dan menguatnya watak menolong 'ambigu' karena berharap hasil yang didapatkan.

Padahal dalam kenyataan di masyarakat, masih diperlukan sebuah transaksi ekonomi untuk membangkitkan keswadayaan masyarakat yang betul-betul dilandasi jiwa menolong sejati. Dalam kerangka ini, pinjam-meminjam adalah 
sebuah transaksi sosial murni karena menolong. Di sinilah fungsi akad Dana Kebajikan (Qardhul Hasan: yaitu meminjam dengan pengembalian tanpa tambahan) sangat dominan. Praktek seperti ini sangat diperlukan pada masyarakat yang baru saja terkena bencana, mengalami kemiskinan akut dan baru pertama kali memulai aktivitas bisnis.

Social Trust Fund (STF) dikembangkan oleh Dompet Dhuafa (DD) untuk memainkan fungsi bank orang miskin yang sesungguhnya. Transaksi dominan yang dikembangkan adalah berbasis kepada akad dana kebajikan (Qardhul Hasan). Pada tahap awal (dua tahun pertama), akad dana kebajikan ini menempati proporsi 100 persen. Sumber dananya berasal dari zakat, infak, sedekah, dana Corporate Social Responsibility (CSR) serta dana sosial lainnya. Kekuatan utama STF adalah betul-betul kepercayaan di antara pengelola dan penerima manfaat.

Dalam tahap lanjut (setelah melewati dua tahun), STF kita perkenankan mempraktekkan transaksi non-Dana Kebajikan dalam rangka menghasilkan pendapatan untuk menopang operasional STF. Transaksi non-Dana Kebajikan ini ditujukan kepada penerima manfaat yang telah mengalami peningkatan kelas sosial dan ekonomi dengan perkembangan usahanya. Untuk memastikan bahwa STF tetap sebagai lembaga sosial, maka proporsi transaksi non-Dana Kebajikan adalah maksimal 40 persen dari rasio keuangan STF. Untuk mengawal agar fungsi sosial STF tetap dominan, badan hukum yang akhirnya digunakan STF adalah Koperasi Sosial. Ini adalah rintisan genre baru koperasi di Indonesia.

STF adalah sebuah bentuk rekayasa sosial dan ekonomi yang sedang kita lakukan. Tugas terbesar kita adalah memastikan bahwa STF tetap entitas berjiwa sosial yang mampu tegak secara berkelanjutan. Lorong sejarah akan menguji dan menyempurnakan semua upaya kita semua.

Manusia adalah makhluk sosial yang tidak bisa hidup tanpa orang lain. Untuk itulah Dompet Dhuafa ada, bersama dengan para relawan membantu saudara-saudara yang tertimpa musibah dan mereka yang tidak tahu arah. Program- program dalam Social Development terus mengalami perkembangan mengikuti dinamika yang terjadi di masyarakat. Program ini dijalankan oleh beragam lembaga di bawah Dompet Dhuafa dan lebih dari 5 tahun telah membantu masyarakat Indonesia. Program-program tersebut akan terus dikembangkan mutu dan variasinya agar dapat memberikan pelayanan maksimal bagi masyarkat khususnya kaum miskin di Indonesia.

Pemberian bantuan langsung kepada mustahik/penerima manfaat yang membutuhkan bantuan mendesak seperti biaya pulang kampung, biaya SPP, biaya tebus ijazah, pembagian sembako, menebus obat di rumah sakit, hingga biaya sewa kontrakan yang terlewat tengat. Golongan penerima bantuan Lamusta adalah sesuai dengan asnaf penerima zakat di antaranya fakir, miskin, dan orang yang berhutang.

Program bantuan terhadap korban bencana alam baik pada saat bencana maupun setelah bencana untuk evakuasi, logistik, rehabilitasi, trauma healing, pengobatan gratis pasca bencana dan recovery pemulihan ekonomi masyarakat. 
Barzah Peduli merupakan program bantuan mobil jenazah bagi dhuafa yang meninggal dunia dan kesulitan untuk memulangkan jenazahnya secara Cumacuma. Selain mengantar jenazah, program ini juga memberikan layanan pemulasaraan jenazah dari mulai memandikan sampai memakamkan jenazah. Selain itu program Barzah juga memberikan pelatihan pemulasaraan jenazah secara gratis bagi masyarakat/sekolah serta bantuan keranda, kain kaffan dan perlengkapan pemulasaraan jenazah bagi masyarakat dhuafa.

Program pemberdayaan Dompet Dhuafa yang memberikan bantuan pengeboran air, pembangunan MCK dan sarana sanitasi air lainnya bagi wilayahwilayah yang mengalami kesulitan air bersih. Program ini melibatkan masyarakat dalam pembangunan dan perawatannya sehingga masyarakat merasa memiliki, dalam program ini juga disisipkan penyuluhan hidup bersih dan sehat agar kualitas kesehatan masyarakat penerima bantuan program ini semakin meningkat. Program pengembangan kemandirian masyarakat miskin dengan cara menanam pohon produktif di wilayah sekitar mereka.

Tugas pokok DMC adalah menjadi garda terdepan pengelolaan kebencanaan, baik dalam maupun luar negeri. Disaster Management Center Dompet Dhuafa selanjutnya disingkat menjadi DMC adalah jejaring pelaksana program kebencanaan Divisi Relief Dompet Dhuafa. Tugas pokok DMC adalah menjadi garda terdepan pengelolaan kebencanaan, baik dalam maupun luar negeri. Kebencanaan yang dimaksud adalah bencana yang diakibatkan oleh peristiwa atau serangkaian peristiwa yang disebabkan oleh alam antara lain berupa ; gempa bumi, tsunami, gunung meletus, banjir, kekeringan, angin topan dan tanah longsor, termasuk di dalamnya kebakaran. Untuk memahami tugas pokok DMC-DD tersebut, maka perlu diketahui terlebih dahulu bahwa terdapat 3 fase utama dalam pengelolaan kebencanaan, meliputi : masa sebelum terjadi bencana (pra bencana), saat terjadi bencana dan setelah terjadi bencana.

Masa sebelum terjadi bencana lebih dikenal sebagai fase mitigasi. Dalam fase ini DMC-DD mengambil peran strategis dalam melakukan kampanye pengurangan resiko bencana berbasis komunitas. Metode yang digunakan antara lain diskusi public berupa seminar, milis, bincang-bincang, training, dsb. Metode lainnya adalah berbasis media, baik media cetak maupun elektronik yaitu berupa leaflet, brosur, website, film, perpustakaan, dsb. Yang tak kalah pentingnya adalah metode role play berbasis komunitas. Metode ini menggunakan nama kampong tanggap bencana disingkat kata bencana. Kata bencana mentargetkan hasil lahirnya kesadaran masyarakat tentang kewilayahan dan potensi bencananya, serta keterlibatan mereka dalam aktivitas pengurangan risiko bencana.

Tahapan berikutnya adalah masa setelah terjadinya bencana. Masa ini terdiri dari 2 bagian besar. Pertama sering disebut sebagai masa pemulihan/recovery. Program-program recovery bertujuan membantu para korban bencana agar segera pulih dari traumannya dan menjalani aktifitas kesehariaannya, seperti trauma healing, sekolah darurat, pelayanan orang cacat dan jompo serta ibu hamil, dan 
lain-lain. Fase ini juga menginisiasi pelibatan komunitas untuk bergabung menjadi relawan aktif membantu aktifitas posko dan pengelolaan pengungsian. Ke dua masa pembangunan kembali/rekonstruksi, yang ditandai dengan pembangunan hunian sementara yang menjadi tempat berteduh para pengungsi untuk $1-2$ tahun, hingga mereka dapat kembali hidup normal di rumah tinggalnya secara permanen. Termasuk pembangunan infrastruktur/sarana/prasarana, fasulitasa umum/social lainnya.

Khusus pengelolaan bencana luar negeri, dalam rangka Diplomasi kemanusiaan, DMC menjadi tim kemanusiaan Dompet Dhuafa yang diutus untuk beberapa tujuan: Memberikan bantuan pragmatis korban sesuai kebutuhan yang paling mendesak; membangun aliansi strategis dalam bentuk jaringan komunikasi dan kerjasama dengan lembaga internasional, regional, maupun lokal di kawasan bencana, hal ini dilakukan dalam rangka mempersiapkan program jangka panjang dan stratgis di lokasi bencana; dan meningkatkan hubungan koordinasi dengan perwakilan Pemerintahan Indonesia di Negara tersebut.

\section{Hasil Implementasi Program Dompet Dhuafa Jawa Barat Dalam Meningkatkan Kepercayaan Muzakki}

Tujuan dari menentukan strategi adalah untuk mencapai suatu tujuan yang diinginkan. Tujuan organisasi itu bisa tercapai sesuai rencana jika para anggota organisasi bisa bersinergis dalam melaksanakan segala tugas-tugas mereka, begitupun bagian marketing Dompet Dhuafa yang mempunyai tugas-tugas tersendiri untuk mencapai visi dan misi Dompet Dhuafa. Dalam hal ini, yang telah terlihat dampak dari pelaksanaan strategi dan implementasi program yang telah dilaksanakan oleh marketing Dompet Dhuafa.

Di bulan Ramadhan 1435 Hijriah, dana zakat, infak, sedekah, dan wakaf (Ziswaf) dari masyarakat yang dihimpun lembaga zakat Dompet Dhuafa berhasil mengalami peningkatan.

Adanya Respon Positif Masyarakat. Salah satu program kerja marketing Dompet Dhuafa adalah membentuk kepercayaan muaakki terhadap lembaga, membentuk kepercayaan yang telah terjalin baik dan bahkan selalu meningkatkankepercayaan tersebut. Untuk menampung saran dan respon masyarakat, Dompet Dhuafa telah menyediakan kotak saran untuk menampung saran-saran dan pendapat masyarakat ataupun opini yang berkembang, selain kotak saran hotline sevice bias dilakukan oleh masyarakat melalui SMS.

Dari hasilnya bahwa masyarakat lebih banyak memberkan pujian atas keputusan yang telah didapat. Indaksi lain mengenai respon positif dari masyarakat adalah antusiasme mereka terhadap kegiatan-kegiatan yang di laksanakan oleh Dompet Dhuafa. Hal ini merupakan salah satu bukti bahwa adanya peningkatan yang dilakukan oleh marketing Dompet Dhuafa dalam meningkatkan kepercayaan muzakeki.

Faktor Pendukung dan Penghambat Penghimpunan Dana Zakat Dompet Dhuafa Jabar. Mudah dan sulitnya dalam pencapaian suatu tujuan penghimpunan dana zakat pada Dompet Dhuafa Jabar tidak terlepas dari faktor- 
faktor yang mendukung dan menghambat penghimpunan dana (fundraising). Adapun faktor pendukung dan penghambat penghimpunan dana zakat tersebut adalah:

Faktor Pendukung Penghimpunan Dana Zakat Dompet Dhuafa Jabar. Faktor pendukung merupakan salah satu penyebab agar supaya penghimpunan dana berjalan dengan lancar dan dapat mencapai target penerimaan dana zakat sesuai yang telah ditentukan. Faktor pendukung ersebut antara lain: Profesionalitas lembaga sejenis semakin berkembang dan mendorong gerakan zakat di daerah. Tekhnologi semakin canggih dan maraknya media massa mupun social network sehingga memberikan kemudahan kepada kalangan masyarakat untuk lebih mengetahui lembaga zakat. Dengan adanya dukungan dari pemerintah dan partisipasi masyarakat dalam melakukan aksi sosial semakin tinggi. Misalnya menganjurkan seluruh Pegawai Negeri dilingkungan pemerintah yang telah mencapai nisab untuk membayar zakatnya di LAZ.

Semakin baiknya manajemen kerelawan (DD Volounter).Untuk menambah kepercayaan masyarakat terhadap Dompet Dhuafa Jabar, maka Dompet Dhuafa Jabar banyak melaksanakan event-event dimana dalam event tersebut Dompet Dhuafa Jabar melakukan kerjasama dengan perusahaan lain. Keunggulan-keunggulan di atas tersebut yang menjadi peluang bagi Dompet Dhuafa Jabar untuk dapat menghimpun dana ZIS sesuai target yang telah ditetapkan.

Faktor Penghambat Penghimpunan Dana Zakat Dompet Dhuafa Jabar Untuk mencapai tujuan sebuah lembaga pasti ada hambatan yang akan ditemuinya, tak terkecuali dengan Dompet Dhuafa Jabar setidaknya ada tiga faktor yang menjadi kelemahan penghimpunan dana pada Dompet Dhuafa Jabar. Tiga faktor tersebut adalah. 1) Sumber Daya Manusia (SDM) baik kualitas maupun kuantitas. Adapun faktor kualitas seperti pengetahuan masyarakat Jatim yang masih minim karena kurang gencarnya sosialisai Dompet Dhuafa Jabar sehingga masyarakat belum begitu faham apa itu penghimpunan (fundraising) dan Dompet Dhuafa, sehingga persepsi masyarakat terhadap lembaga Dompet Dhuafa Jabar sebagai lembaga peminta-minta serta budaya masyarakat tentang berzakat yang masih suka membayarkan zakat, infak atau sedekahnya langsung kepada mustahik. Sedangkan faktor kuantitasnya terkait dengan kurangnya jumlah tenaga dilapangan dalam melaksanakan kegiatan fundraisingnya. 2) Kuantitas sumber daya manusia tanpa disertai dengan kualitas yang baik akan menjadi kurang efisein. Untuk mengatasi kendala tersebut, Dompet Dhuafa Jabar perlu meningkatkan SDM karyawan dengan cara memberikan pelatihan yang diadakan oleh DD Jabar serta sharing antar karyawan terkait dengan kesulitan yang dialaminya. 3) Accountablity, yaitu terkait laporan keuangan, laporan penyaluran, dimana kecenderungan donatur melihatnya kurang berminat untuk menyalurkan dananya ke lembaga tersebut, bahwa lembaga amil zakat cenderung dipandang sebagai lembaga sosial/ lembaga 
peminta-minta, padahal LAZ adalah sebagai lembaga intermedite dimana berada ditengah-tengah antara muzakki dan mustahik.

Kebijakan, dimana undang-undang No.23 tahun 2011 ini sangat berat tantangannya, karena LAZ harus berbentuk lembaga berbadan hukum, bersedia di audit syariat dan keuangan secara berkala, tidak boleh mendirikan cabang di provinsi lebih dari satu, serta LAZ wajib melaporkan pelaksanaan pengumpulan, pendistribusian, dan pendayagunaan zakat yang telah diaudit kepada BAZNAS secara berkala.

\section{PENUTUP}

Setelah penulis mengadakan penelitian terhadap Strategi Marketing Dompet Dhuafa Dalam Meningkatkan Kepercayaan Muzakki dan berdasarkan uraian yang penulis uraikan dari hasil penelitian tersebut, maka penulis mengambil kesimpulan sebagai berikut. Yang dilakukan marketing zakat dompet dhuafa jabar dalam mengkaitka kepercayaan murakki yaitu ada dua tahap yaitu: pertama, Direct marketing dalam model direct marketing dompet dhuafa menggunakan dua metode, yaitu: offline dan online. Offline adalah metode yang digunakan marketing secara langsung seperti face to face antara Amil (petugas dompet dhuafa) dengan muzakeki (donator), penyebaran brosur, pamphlet dan lain-lain. Kedua In Direct Marketing, In Direct Marketing adalah bentuk metode fundraising yang dilakukan dompet dhuafa dalam bentuk iklan melalui media masa seperti iklan melalui televise, radio, dan Koran.

Implementasi dari strategi marketing dompet dhuafa dalam meningkatkan kepercayaan muqakki adalah melalui program yaitu Kesehatan, Pendidikan, Sosial Devlopment, Ekonomi, dan program incidental seperti bulan Ramadan dan Qurban. Hasil dari implementasi marketing dompet dhuafa dalam meningkatkan kepercayaan mu₹akki yaitu terlihat dari meningkatnya jumlah donator setiap tahunnya. Dan masyarakat lebih banyak memberkan pujian atas keputusan yang telah didapat. Indaksi lain mengenai respon positif dari masyarakat adalah antusiasme mereka terhadap kegiatan-kegiatan yang di laksanakan oleh Dompet Dhuafa. Hal ini merupakan salah satu bukti bahwa adanya peningkatan yang dilakukan oleh marketing Dompet Dhuafa dalam meningkatkan kepercayaan muzakeki.

Strategi marketing dompet dhuafa jabar dalam meningkatkan kepercayaan muqakki dirasakan sangat penting dan harus dilaksanakan seuruhnya. Oleh karena itu di harapkan seluruh pengurus maupun marketing dompet dhuafa harus lebih mengoptimalkan strategi tersebut agar mampu memberikan program yang maksimal kepeda seluruh muqakki, terutama muzakki kota Bandng. Bagi pegurus dompet dhuafa agar memaksimalkan kinerjanya dalam melaksanakan program maupun pada tranparansi dana agar menjadi lembaga yang amanah sehingga di percaya oleh muzakki .Bagi pihak peneliti dan akademis, peneliti merekomendasikan untuk terus mengembangkan potensi-potensi yang dapat digali untuk diteliti lebih jauh dalam pengembangan marketing dompet duafa. 
Pola Pengelolaan Manajemen Zakat dalam Mengatasi Kemiskinan ...

Peneliti hanya menggali satu dimensi saja dari marketing dompet dhuafa jabar dan masih banyak dimensi-dimensi lain yang menarik untuk ditindak lanjuti secara mendalam.

\section{DAFTAR PUSTAKA}

A Umara, 2006, Implementasi Manajemen Stratejik, Kebijakan Dan Proses. Yogyakarta: Amara Books.

Agustinus, Sri Wahyudi. 1996, Manajemen Strategik, Pengantar Proses Berfikir Strategic. Jakarta: Binarupa Aksara.

Ahmad, Juwaini, 2005, Panduan Direct Mail untuk Fundraising. Jakarta: Piramedia. April, Purwanto, 2009, Manajemen Fundraising bagi Organisasi Pengelola Zakat. Yogyakarta: Sukses.

Asep Iwan Setiawan, (2012). Dakwah Berbasis Pemberdayaan Ekonomi dan Peningkatan Kesejahteraan Mad'u. Imu Dakwah: Academic Journal for Homiletic Studies. 6(2). 347-262.

Bilson, Simamora. 2001. Memenangkan Pasar dengan Pemasaran Efektif dan Profitabel. Jakarta: PT. Gramedia Pustaka Umum.

Direktorat Pemberdayaan Zakat, 2009, Manajemen Pengelolaan Zakat.

Djaslim, Saladin, 2003, manajemen strategic. Bandung: Linda Karya

Hendra,Sutisna, 2006, Fundraising Database, Jakarta: Piramedia.

Miftahul, Huda, 2012, Pengelolaan Wakaf dalam Perspektif Fundraising. Jakarta: Kementrian Agama RI.

Prisgunanto, Ilham. 2006, Komunikasi Pemasaran : Ghila Indonesia

Rachmat, jalaluddin, 2005, Psikologi Komunikasi. Jakarta: PT. Raja Grafindo Perseda.

Ruslan, Rosady, 2010, Metode Penelitian, Public Relation Dan Komunikasi. Jakatra: PT. Raja Grafindo Perseda.

S.P Hasibuan, melayu, 2006, Manajemen Dasar, pengertian, dan Masalah. Jakarta: Bumi Aksara.

Sulastri, Lilis, 2010, Sumber Daya Manusia Strategik. Bandung: La Goods Publishing.

Syaikh Muhammad bin Shalih Al-Ustmani, 2008, Fatwa-fatwa Zakat. Jakarta: Darussunnah Pres.

Umrotul, Hasanah, 2010, Manajemen Zakat Modern. Malang: UIN Maliki Pres.

Warlen J Keegan, 2003, Manajemen Pemasaran Global. Jakarta: Indeks

Yeremias, T Keban, 2004, Enam Strategis Administrasi Publik, Konsep, Teori, Dan Isu. Yogyakarta: Grava Media. 